\title{
Analisis Kemampuan Pemecahan Masalah dan Respon Peralihan Matematik dari SMP ke SMA pada Materi SPLTV
}

\author{
Siti Zakiyah ${ }^{*}$, Wahyu Hidayat ${ }^{2}$, dan Wahyu Setiawan ${ }^{3}$ \\ 1*,2,3Pendidikan Matematika, IKIP Siliwangi \\ Jalan Terusan Jendral Sudirman, Cimahi, Jawa Barat, Indonesia \\ 1*zakiyahsugandi@gmail.com, ${ }^{2}$ wahyu.azam.hidayat@gmail.com, ${ }^{3}$ kakwahyu3@gmail.com
}

Artikel diterima: 15-01-2019, direvisi: 26-05-2019, diterbitkan: 31-05-2019

\begin{abstract}
Abstrak
Pemecahan masalah merupakan suatu kemampuan yang sangat kompleks di mata siswa. Tujuan dari penelitian ini untuk mengetahui dan menganalisis kemampuan pemecahan masalah matematik siswa SMA kelas $X$ dan respon peralihan matematika SMP ke SMA terhadap materi SPLTV. Penelitian ini berbentuk deskriptif kualitatif dengan objek penelitian siswa kelas $X$ di salah satu SMA di Bandung Barat. Instrumen dalam penelitian ini adalah uji soal kemampuan pemecahan masalah dan angket kemampuan matematika siswa apabila ditinjau dari peralihan SMP ke SMA terhadap materi SPLTV. Jumlah soal yang digunakan dalam penelitian ini adalah sebanyak empat dari enam butir soal yang disediakan dengan angket yang berisikan sepuluh pertanyaan, yang terdiri dari empat pertanyaan tertutup dan enam pertanyaan terbuka. Penelitian ini dilaksanakan pada tanggal 10 September 2018 dan 8 Oktober 2018. Kemampuan pemecahan masalah matematik siswa kelas X di Bandung Barat terhadap materi SPLTV tergolong tinggi, dengan persentase sebesar $79,868 \%$. Siswa yang memiliki latar belakang pemahaman SPLDV yang baik cenderung mudah memahami SPLTV dengan baik pula.

Kata Kunci: pemecahan masalah matematis, deskriptif kualitatif, SPLTV.

\section{Analysis of Problem Solving Ability and Respons of Transition from Junior to Senior High School in SPLTV Material}

Abstract

Problem-solving is problem-solving in the eyes of students. The purpose of this study was to study and analyze the mathematical problem solving of high school students in class $X$ and the response of the transition of junior high school to high school to SPLTV material. This research is in the form of qualitative descriptive research with class $X$ objects in one of the high schools in West Bandung. The instruments in this study were problem-solving questions and mathematical ability questionnaires which were reviewed from the transition of junior high school to high school to SPLTV material. The number of questions used in this study amounted to four of the six items provided with a questionnaire containing questions, which consisted of four closed questions and six open questions. This research was conducted on September 10, 2018, and October 8, 2018. The ability to solve the problems of grade $X$ students in West Bandung on SPLTV material was high, with a contribution of $79.868 \%$. Students who have a background in understanding SPLDV can easily consider SPLTV well too.

Keywords: mathematics problem solving, qualitative descriptive, SPLTV.
\end{abstract}




\section{Pendahuluan}

Jhonson dan Rising (Ruseffendi, 1990) mengemukakan pendapatnya mengenai matematika, yaitu sebuah bahasa yang menggambar dengan cermat; jelas dan akurat; dan dipresentasikan dengan menggunakan simbol. Bahasa inilah yang digunakan manusia dalam berkomunikasi atau berhubungan sosial dan memecahkan permasalahan sosial. Seperti yang dikatakan oleh Kline (Ruseffendi, 1990) matematika bukanlah ilmu yang dapat berdiri dengan sendirinya dan dapat sempurna dengan sendirinya, tetapi keberadaan matematika berperan dalam membantu manusia hidup menyelesaikan permasalahan sosial, ekonomi, dan juga ilmu alam.

Keberadaaan matematika tidak hanya berguna sebagai sebuah ilmu hitung menghitung. Namun, keberadaan matematika juga mampu meningkatkan daya analisis, sintesis dan evaluasi seseorang. Sehingga kemampuan memecahkan permasalahan seseorang dapat digambarkan dari cara ia menyelesaikan permasalahan matematika. Oleh karena itu, dalam menyelesaikan soal-soal matematika dapat diselesaikan degan kemampuan pemecahan masalah matematik yang ia miliki.

Sedangkan Gagne mengemukakan bahwa pemecaan masalah merupakan tahapan belajar paling tinggi diantara pembelajaran menggunakan isyarat; pembelajaran menggunakan rangsangan respon; pembelajaran berantai; mengasosiasi secara verbal; membedakan; pembelajaran berkonsep; dan pembelajaran menggunakan aturan (Zakiyah, Imania, Rahayu, dan Hidayat, 2018). Pantas apabila NCTM mengemukakan bahwa pemecaham masalah jantungnya matematika (Zakiyah, Imania, Rahayu, \& Hidayat, 2018).

Pemecahan masalah dapat juga berperan sebagai suatu kemampuan (kemampuan pemecahan masalah) sangatlah kompleks, bahkan lebih kompleks dari definisi pemecahan masalahnya itu sendiri (Afriansyah, 2016). Pemecahan masalah matematik adalah sebuah soal atau masalah yang dapat diselesaikan, tetapi tidak dengan otomatis bisa mengerjakannya karena belum ada aturan atau prosedur untuk mengerjakannya (Ruseffendi, 1990). Pemecahan yang menjadi pusat utama adalah proses dari pada jawaban yang benar (Ruseffendi, 1990).

Polya (Siswono, 2018) mengemukakan, bahwa dalam memecahkan suatu permasalahan terdapat empat tahapan, yaitu: (1) memahami masalah, (2) membuat langkah-langkah dalam merencanakan penyelesaian, menyelesaikan rencana penyelesaian, (4) memeriksa kembali. Krulik dan Rudnick (Siswono, 2018) mengemukakan langkahlangkah dalam memecahkan sebuah masalah adalah sebagai berikut: membaca dan berpikir; mengeksplorasi dan merencanakan; menyeleksi suatu strategi; mencari suatu jawaban; serta memperluas dan merefleksi. 
Hidayat dan Sariningsih (2018) mengemukakan, bahwa dalam menyelesaikan suatu permasalahan diperlukan beberapa ketermpilan dalam memahami sebuah masalah, membuat suatu model matematika dari permasalahan tersebut, menyelesaikan masalah dan menafsirkan solusinya. Langkah-langkah pemecahan masalah dapat membantu siswa menyelesaikan pembelajaran matematika, dimana langkah-langkahnya adalah memahami masalah; merencanakan model matematika; menyelesaikan model dan membuat solusi (Nur, Maya, \& Setiawan, 2018).

Masih banyak lagi para ahli yang mengemukakan langkah-langkah dari kemampuan pemecahan masalah, namun peneliti menganut tahapan pemecahan masalah yang dikemukakan oleh George Polya dalam penelitian ini. Dalam memecahkan pemecahan masalah diperlukan beberapa keterampilan, seperti: (1) keterampilan dalam berhitung dan mengukur, (2) keterampilan menghadapi situasi yang umum terjadi, (3) berfikir terhadap situasi baru.

Van De Walle (Ariani, Hartono, \& Hiltrimartin, 2017) menyatakan bahwa ketika siswa dilibatkan dalam tugas-tugas yang menekankan pada pemecahan masalah dan juga pada metode-metode saat memecahkan sebuah masalah maka dengan sendirinya siswa akan menemukan pemahaman-pemahaman barunya dalam matematika. Ketika siswa dilibatkan dalam memecahkan permasalahan matematika maka akan membantu siswa dalam memahami matematika dengan baik karena siswa secara aktif dilibatkan dalam berpikir matematika pada saat ia melakukan manipulasi, bereksperimen, dan menyelesaikan masalah (Setiawan, 2015). Pembelajaran Berbasis Masalah (PBM) adalah salah satu pembelajaran yang dapat mengkontruktivisme pemahaman siswa (Sumarmo, Hidayat, Zulkarnaen, Hamidah, \& Sariningsih, 2012).

Kemampuan pemecahan seseorang dipengaruhi oleh beberapa faktor yang dilatarbelakangi oleh: (1) pengalaman awal, (2) latar belakang, (3) keinginan dan motivasi, dan (4) struktur masalah (Siswono, 2018). Pengalaman awal dan latar belakang matematik inilah yang akan peneliti teliti sebagai tindakan dari analisis kemampuan pemecahan matematik siswa SMA terhadap materi SPLTV. Pengalaman awal siswa mengenai matematik khususnya materi SPLDV di tingkat SMP sebagai syarat dalam memahami materi SPLTV di tingkat SMA, dan latar belakang siswa dalam bermatematik inilah yang akan peneliti teliti melalui beberapa pernyataan yang termuat dalam sebuah angket.

Penelitian ini bertujuan untuk memberikan gambaran mengenai kemampuan siswa SMA dalam memecahkan masalah matematika terhadap materi SPLTV berdasarkan tahapan pemecahan masalah yang siswa berikan, serta menggambarkan respon siswa mengenai matematika dan 
pembelajaran matematika SMP terutama materi SPLDV, menggambarkan respon siswa mengenai matematika dan pembelajarannya pada jenjang SMA terutama SPLTV, dan keterkaitan antara keduanya.

\section{Metode}

Dengan adanya penelitian ini memiliki tujuan untuk mengetahui dan menganalisis kemampuan pemecahan masalah matematik dari siswa SMA kelas $X$ ditinjau dari peralihan matematik SMP ke SMA Terhadap Materi SPLTV. Sampel dalam penelitian ini sebanyak 19 orang siswa kelas X di salah satu SMA di Bandung Barat. Metode dalam penelitian ini adalah deskriptif kualitatif, yaitu penelitian menggambarkan secara utuh dan mendalam tentang realita sosial dan berbagai kajadian alam yang terjadi di masyarakat yang menjadi subjek penelitian sehingga tergambarkan ciri, karakter, model, dan sifat dari berbagai kejadian tersebut (Sanjaya, 2013). Instrumen yang digunakan adalah empat dari enam butir soal uraian yang mana soal nomor $1,2, \&$ 3 wajib untuk diisi dan angket yang berisi pertanyaan tertutup dan terbuka. Anget berisi sepuluh buah pertanyaan, yang memuat empat buah pertanyaan tertutup dan enam buah pertanyaan terbuka. Penelitian mengenai uji kemampuan pemecahan masalah matematik ini dilaksanakan pada 10 September 2018, dan penelitian mengenai pembelajaran matematika ditinjau dari peralihan SMP ke SMA pada materi SPLTV dilaksanakan pada 230
8 Oktober 2018. Dalam melakukan pengolahan data pada penelitian ini penulis menggunakan bantuan Softwere Microsoft Excel 2010. Sedangkan tahapan yang menjadi tolak ukur dalam menilai kemampuan pemecahan masalah matematik ini adalah, memahami masalah, menyusun rencana penyelesaian, melaksanakan rencana penyelesaian, dan menentukan kesimpulan dari permasalahan tersebut. Dalam penelitian ini, kami mengklasifikasikan kemampuan berdasarkan persentase yang dibagi menjadi kriteria-kriteria tertentu, yang disajikan dalam tabel 1.

Sedangkan kriteria dalam mengklasifikasikan tingkat kesukaran, kesenangan, dan kesukaan dalam penelitian ini, peneliti mengklasifikasikannya menjadi kriteriakriteria pada tabel 2.

Tabel 1.

Kriteria Klasifikasi Persentase (Riduan, 2007)

\begin{tabular}{|cc|}
\hline Kriteria & Klasifikasi \\
\hline $\mathbf{0} \leq \boldsymbol{N} \leq \mathbf{2 0}$ & Sangat Rendah \\
\hline $\mathbf{2 0}<\boldsymbol{N} \leq \mathbf{4 0}$ & Rendah \\
\hline $\mathbf{4 0}<\boldsymbol{N} \leq \mathbf{6 0}$ & Sedang \\
\hline $\mathbf{6 0}<\boldsymbol{N} \leq \mathbf{8 0}$ & Baik \\
\hline $\mathbf{8 0}<\boldsymbol{N} \leq \mathbf{1 0 0}$ & Sangat Baik \\
\hline
\end{tabular}

Tabel 2.

Kriteria Klasifikasi Kesukaan, Kesenangan, dan Kesulitan

\begin{tabular}{cc}
\hline Kriteria & Klasifikasi \\
\hline $\mathbf{0} \leq \boldsymbol{N} \leq \mathbf{1}$ & Tinggi \\
\hline $\mathbf{1}<\boldsymbol{N} \leq \mathbf{2}$ & Sedang \\
\hline $\mathbf{2}<\boldsymbol{N} \leq \mathbf{3}$ & Rendah \\
\hline
\end{tabular}




\section{HaSil dan Pembahasan}

Hasil dalam penelitian ini akan disajikan dalam tabel 3 dan 4.

Pertama-tama penulis akan memberikan gambaran dari kemampuan siswa SMA di Bandung Barat dalam memecahkan permasalahanpermasalahan matematik yang ditinjau dari tahapan pemecahan masalah, untuk memperjelas apa yang akan penulis paparkan (lihat tabel 3). Berdasarkan isi dari tabel tersebut, dapat dilihat bahwa kemampuan siswa dalam menjawab permasalahan berdasarkan langkah demi langkah dalam memecahkan masalah mengamali penurunan. Sejalan dengan penelitian peneliti sebelumnya mengenai kemampuan siswa SMA dalam memecahkan masalah matematik, Zakiyah, Imania, Rahayu, dan Hidayat (2018) kemampuan siswa memecahkan masalah dari tahap awal hingga ke akhir mengalami penurunan. Hasil dari tahap awal pemecahan masalah ini, dengan banyaknya sampel sebanyak 19 siswa dan skor maksimum sebesar 25 diperoleh jumlah skor 450 dengan rerata 19,56522, dan diperoleh juga persentase 94,73684\%, atau tahap memahami masalah pada diri siswa sudah sangat baik dipahami oleh siswa. Tahap memahami masalah ini memperoleh hasil yang sama dengan tahap memahami masalah yang dilakukan dalam penelitian Zakiyah, Imania, Rahayu, dan Hidayat (2018) yang mengatakan bahwa, tahap pertama ini berkategori sangat tinggi dengan persentase 83,3\%.

Sedangkan untuk tahap selanjutnya, tahap menyusun rencana penyelesaian dengan skor maksimum sebesar 25, didapatkan jumlah skor sebanyak 435 dan rerata 18,91304, sehingga didapatkan persentase sebesar 91,57895\% atau tergolong sangat baik.

Selanjutnya, untuk tahap ketiga, tahap menyelesaikan rencana penyelesaian, skor maksimum 25, didapatkan jumlah skor sebanyak 392,5 dan rerata 17,06522, dengan itu diperoleh persentase sebesar $82,63158 \%$ yang mana persentase tersebut masih dapat dikatakan kategori sangat baik.

Untuk tahap terakhir dalam kemampuan memecahkan permasalahan matematik ini, verifikasi dan informasi hasil, atau dalam dunia soal matematika dikatakan himpunan penyelesaian atau kesimpulan dari apa yang ditanyakan. Dalam tahap ini, dengan jumlah sampel dan skor maksimum yang sama,

Tabel 3.

Hasil Kemampuan Pemecahan Masalah Siswa Berdasarkan Tahapan Pemecahannya

\begin{tabular}{|lcccccc}
\hline \multicolumn{1}{c}{ Tahapan Pemecahan Masalah } & SMI & Jumlah & Rerata & $\%$ & Kategori \\
\hline Memahami masalah & 25 & 450 & 19,565 & 94,737 & Sangat Baik \\
\hline Menyusun rencana penyelesaian & 25 & 435 & 18,913 & 91,579 & Sangat Baik \\
\hline Melaksanakan rencana penyelesaian & 25 & 392,5 & 17,065 & 82,632 & Sangat Baik \\
\hline Verifikasi dan informasi hasil & 25 & 240 & 10,435 & 50,526 & Sedang \\
\hline Total & 100 & 1517,5 & 16,495 & 79,868 & Baik
\end{tabular}


didapatkan jumlah skor 240 dan rerata 10,43478, sedangkan jika dikonversikan dalam persentase didapatkan angka $50,52632 \%$ atau tergolong kategori sedang. Sehingga dapat dikatakan bahwa tahap akhir dalam pemecahan masalah ini tergolong kemampuan yang sedang.

Selanjutnya adalah analis kemampuan pemecahan masalah berdasarkan nomor soal (lihat tabel 4), untuk memahaminya lebih dalam. Jumlah soal dalam uji soal ini adalah enam soal yang mana siswa memilih empat soal dengan soal nomor 1 , 2, dan 3 wajib diisi. Untuk soal yang pertama, dengan sekor maksimum sebanyak 30 dan banyak sampel yang sama, didapatkan jumlah skor sebesar 472,5 dan rerata sebesar 24,86842, sehingga diperoleh persentase sebesar 82,89473\%, atau dikatakan dalam menjawab soal tipe nomer satu ini siswa tergolong sangat baik.

Soal nomor dua, dengan skor maksimuum sebesar 20 dan dengan banyaknya sampel yang sama, didapatkan jumlah skor sebesar 355 didapatkan rerata sebesar 18,68421 dan didapatkan pula persentase sebesar 93,42105\%. Sehinggan kategori yang diperoleh siswa pada tahap ini adalah sangat baik.
Soal nomor tiga dalam uji soal ini, skor maksimumnya sebesar 20 poin dan jumlah sampel yang sama didapatkan jumlah skor sebesar 330 dan rerata sebsesar 17,36842, dan dipatkan pula persentase sebesar $86,84210 \%$. Oleh karena itu, dapat dikatakan bahwa kemampuan siswa dalam menyelesaikan soal kemampuan pemecahan masalah pada soal bertipe soal ketiga ini tergolong sangat baik.

Untuk soal nomor terakhir ini, dengan skor maksimum sebesar 30 dan jumlah sampel yang dama, didapatkan jumlah skor sebesar 360 dan rerata sebesar 18,94736, juga didapatkan persentase sebesar 63,15789\%. Sehingga dalam menyelesaikan soal bertipe soal nomor empat ini siswa memiliki kemampuan yang baik.

Dengan jumlah total 1517,5 dan rerata total 16,494565 dan persentase total yang mendekati $80 \%$, yaitu 79,86842\%, maka kemampuan pemecahan masalah matematik siswa dikategorikan berkemampuan pemecahan masalah matematik yang baik. Penelitian ini sejalan dengan yang dilakukan oleh Kurniawati dan Rizkianto (2018) bahwa kemampuan pemecahan masalah sudah mencapai kategori baik, sebesar 78\%. Yuleawati

Tabel 4.

Hasil Kemampuan Pemecahan Masalah Siswa Berdasarkan Nomor Soal

\begin{tabular}{|lcccccc|}
\hline & Soal & SMI & Jumlah & Rerata & $\%$ & \multicolumn{1}{c}{ Kategori } \\
\hline 1 & 30 & 472,5 & 24,868 & 82,894 & \multicolumn{2}{c}{ Sangat Baik } \\
\hline 2 & 20 & 355 & 18,684 & 93,421 & Sangat Baik \\
\hline 3 & 20 & 330 & 17,368 & 86,842 & Sangat Baik \\
\hline 4 & 30 & 360 & 18,947 & 63,158 & Baik \\
\hline Total & 100 & 1517,5 & 16.495 & 79.868 & Baik \\
\hline
\end{tabular}


mengemukakan bahwa, salah satu peran guru dalam pembelajaran matematika adalah membantu penyelidikan yang dilakukan oleh siswa dalam memecahkan masalah, misalnya meminta peserta didik menceritakan langkah yang ada dalam pemikirannya (Kafiar, Kho, \& Triwiyono, 2015). Kemampuan pemecahan masalah merupakan kemampuan yang nyata yang bersumber dari usaha siswa sehingga dalam pembelajarannya dibutuhkan cara dan bahan dalam pengejaran yang nyata juga (Rahayu \& Afriansyah, 2015).

Sehingga, angka 79,86842\% dalam kemampuan pemecahan masalah matematik ini, tidak hanya menunjukkan baiknya kemampuan pemecahan masalah yang dimiliki, tetapi juga menunjukkan tingkat keberhasilan guru dalam membimbing siswa dalam menyampaikan langkah-langkah penyelesaian masalah yang ada dalam pikiran siswa. Baik itu merupakan guru dengan materi yang bersangkutan atau pun kesuksesan guru matematika di tingkat sebelumnya, seperti SD dan SMP. Atau gabungan dari kesuksesan keduanya, sehingga menghasilkan siswa yang dewasa dalam memecahkan permasalahan matematika.

Berikut merupakan salah satu hasil jawaban siswa dalam menjawab pertanyaan nomor satu, yang disajikan dalam gambar 1 .

Siswa dapat menyelesaikan soal dengan sangat tepat (lihat gambar 1). Tahap pertama, yaitu memahami masalah, dalam tahap ini siswa sudah sangat mahir dalam mengkonstruksikan apa yang diketahui dalam soal menjadi model matematika yang sesuai. Selanjutnya tahap menyusun rencana penyelesaian. Dalam tahap ini rencana tidak diperlihatkan secara tertulis, namun dapat dilihat dari bagaimana cara siswa dalam melaksanakan rencana penyelesaian. Siswa dapat menyelesaikan soal tersebut dengan sangat benar dan dapat memberikan verifikasi atau informasi hasil dengan benar (lihat gambar

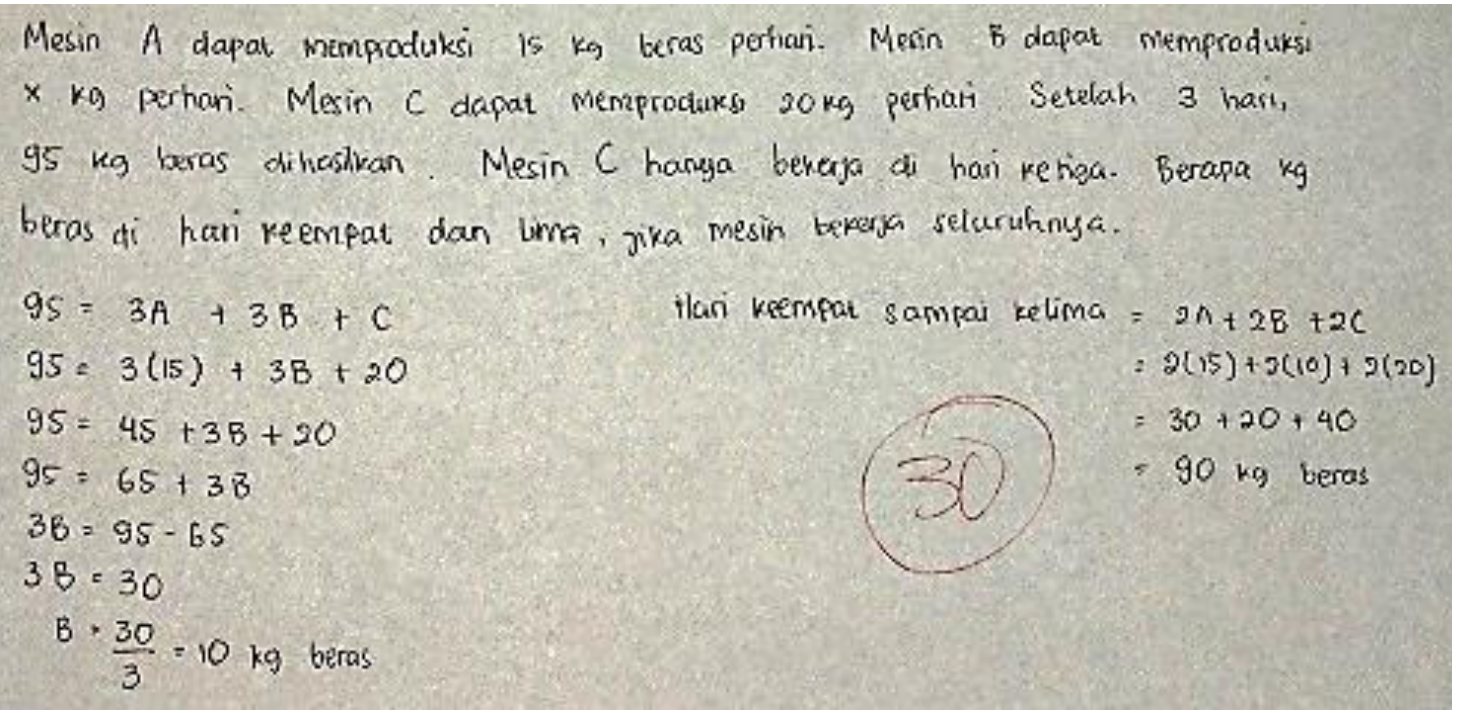

Gambar 1. Salah Satu Jawaban Siswa Nomor Satu. 
1).

Gambar 2 ini merupakan gambar yang menunjukkan kemampuan siswa dalam memecahkan masalah dalam soal nomor dua. Bentuk dari soal ini merupakan sebuah soal pemecahan masalah yang tergolong soal jebakan. Yang mana jika siswa jeli dengan model-model matematika yang telah diketahui, maka akan mudah dan singkat dalam menjawab permasalahan nomor dua ini. Dalam jawaban soal nomor dua ini, siswa dapat menyelesaikan soal dengan sangat singkat, padat, dan benar. Dalam tahapan memahami permasalahan, siswa sudah melaksanakannya dengan sangat benar, dan juga dalam menyusun rencana penyelesaian siswa sangat mahir dalam menyusun rencana atau strategi tersebut. Terlihat dari cara siswa yang mampu menyelesaikannya dengan cara yang tepat. Hal ini juga sejalan dengan tahap selanjutnya, melaksanakan rencana penyelesaian. Dalam tahap melaksanakan rencana penyelesaian ini siswa sudah sangat mahir dalam melaksanakannya. Walau pun terdapat salah satu siswa yang terkecoh dalam menentukan strateginya. Dari segi menjawabnya siswa sudah benar, namun dalam meilih strateginya siswa kurang tepat. Siswa tersebut memilih cara yang membutuhkan pengerjaan yang panjang, namun setelah diamati kembali siswa baru menyadarinya bahwa soal tersebut hanya memerlukan penyelesaian yang sangat mudah. Sedangkan untuk verifikasi jawaban, dilihat dari cara siswa menyelesaikan sampai kepada apa yang ditanyakan dalam soal, dengan adanya hal ini pun sudah menunjukkan bahwa siswa tersebut memiliki kemampuan verifikasi yang baik.

Dalam menganalisis hasil jawaban siswa pada nomor tiga ini, dapat dilihat pada gambar 3. Gambar ini menunjukkan salah satu jawaban siswa dalam menjawab soal nomor tiga. Dalam menjawab soal nomor tiga ini, rata-rata siswa dapat menyelesaikannya dengan baik. Jika dilihat dari tahap memahami masalah, dengan melihat hasil jawaban siswa yang diawali dengan mencari tahu dan menganalisis apa yang diketahui dalam permasalahan tersebut dengan sangat baik, terbukti

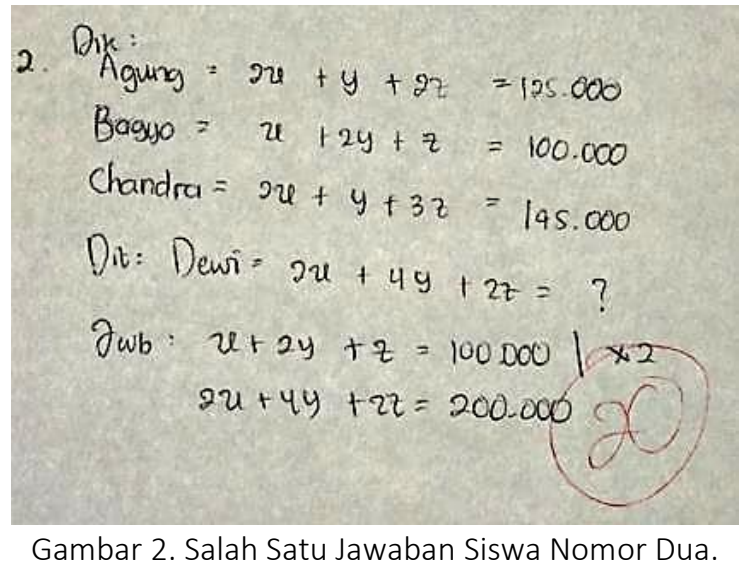


bahwa siswa sudah memiliki kemampuan memahami permasalahan dengan baik. Tahap selanjutnya, membuat strategi penyelesaian. Yang dinilai dalam tahap ini, yaitu dengan melihat bagaimana cara siswa melaksanakan rencana penyelesaian. Terlihat bahwa cara siswa dalam menjawab permasalahan sangatlah benar, dengan menggunakan strategi penyelesaian yang mudah, tidak berbelitbelit, namun tetap menghasilkan apa yang akan dicari. Selanjutnya tahap verifikasi atau menentukan jawaban berdasarkan apa yang ditanyakannya. Dalam tahap ini siswa sudah menjawab dengan sangat baik berdasarkan apa yang ditanyakan dalam permasalahan tersebut.

Dalam menganalisis hasil jawaban siswa pada nomor empat ini, dapat dilakukan dengan melihat gambar 4. Dalam gambar terlihat bahwa dalam tahap memahami masalah, merencanakan pemecahan

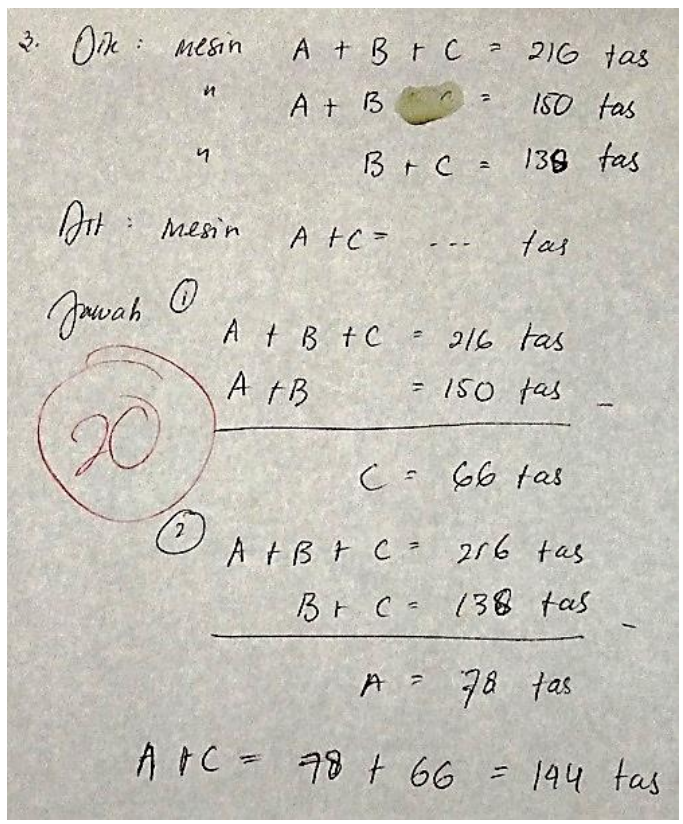

Gambar 3. Salah Satu Jawaban Siswa Nomor Tiga. masalah, dan melaksanakan pemecahan masalah dengan baik. Namun, dilihat dari tahapan selanjutnya, memberikan verivikasi permasalahan, siswa masih terdapat ketidak telitian dalam melaksanakan rencana penyelesaian tersebut, sehingga dalam memberikan verifikasi atau penyelesaiannya pun tidak dapat dijawab dengan benar. Walau pun langkah siswa dalam melakukan verifikasi tersebut sudah benar. Sejalan dengan hasil perhitungan kemampuan siswa dalam melakukan verivikasi masalah di atas, bahwa kemampuan siswa dalam tahap tersebut masih tergolong sedang. Sehingga dalam soal nomor empat ini siswa dikategorkan memiliki kemampuan yang baik. Sedangkan untuk kemampuan memecahan masalah pada nomor satu, dua dan tiga siswa dikategorikan memiliki kemampuan yang sangat baik.

Berikut adalah analisis mengenai

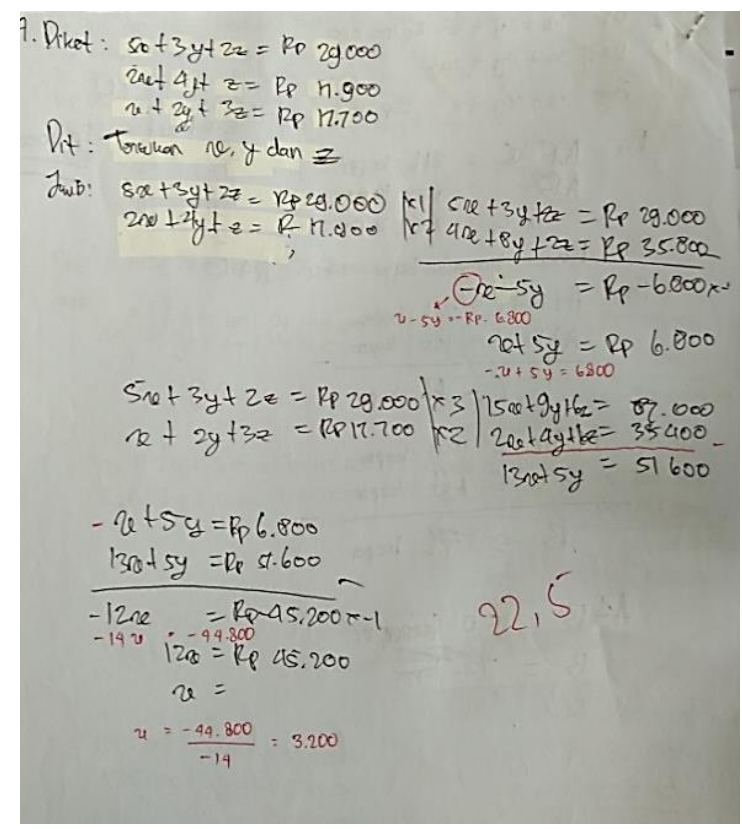

Gambar 4. Salah Satu Jawaban Siswa Nomor Empat. 
kemampuan matematik siswa ditinjau dari peralihan SMP ke SMA terhdap materi SPLDV. Dalam melakukan penelitian ini, penulis menggunakan angket berbentuk campuran (tertutup dan terbuka), yang terdiri dari sepuluh pertanyaan. Angket ini memuat empat pertanyaan tertutup dan enam pertanyaan terbuka.

Berdasarkan respon siswa mengenai matematika, siswa mengatakan bahwa ia menyenangi matematika, tidak terlalu menyukai matematika, bahkan terdapat siswa yang tidak menyukai matematika. Siswa yang menjawab bahwa ia menyukai dan tidak terlalu menyukai matematika sebesar 40\%, sedangkan yang tidak menyukai matematika yaitu 20\%. Bila dirata-ratakan maka siswa menyukai matematika, dengan nilai rata-rata 2,2. Sedangkan untuk tingkat kesulitan matematika berdasarkan respon siswa adalah, 10\% siswa mengatakan bahwa matematika itu mudah, 70\% sedang dan 20\% mengatakan bahwa matematika itu sukar. Sehingga dapat disimpulkan bahwa matematika merupakan mata pelajaran yang tergolong tidak terlalu sukar, dengan rata-rata 1,9 . Siswa juga mengungkapkan alasan-alasan yang menjadi latar belakang matematika tergolong mata pelajaran yang tidak terlalu sukar, bahkan tergolong sulit, yaitu: rasa malas ketika berhitung, caranya yang panjang, sulit, dan susah dimengerti, malas belajar, dan tidak suka berhitung.

Dalam pembelajaran matematika di tingkat SMP dan SD, siswa telah diajarkan beberapa konsep dasar dalam 236 matematika. konsep-konsep dasar inilai yang nantinya menjadi bekal dalam mempelajari matematika di tingkat SMA, terutama dalam materi SPLTV. Konsepkonsep dasar matematika tersebut adalah operasi pertambahan, pengurangan, perkalian, pembagian, pecahan, operasi aljabar, operasi bilangan bulat, Sistem Persamaan Linier Dua Variabel (SPLDV), dan lainnya. Dalam pencapaian siswa terhadap konsep-konsep dasar matematika diatas, 70\% dari siswa yang telah memahami dengan betul semua konsep dasar matematika di atas. Namun, masih terdapat siswa yang belum memahami dengan betul mengenai operasi bilangan bulat, operasi aljabar, dan SPLDV. Sehingga dapat ditarik kesimpulan bahwa sebagian besar siswa memahami dengan betul konsep-konsep dasar matematik. Terdapat faktor-faktor yang menjadi penyebab di balik ketidak pahaman siswa terhadap konsep-konsep dasar matematika di atas, yaitu: malas belajar karena tidak minat matematika, tidak adanya sarana dan prasarana yang mendukung, tidak adanya buku latihan soal, dan tidak suka berhitung.

Berikut adalah respon siswa mengenai pembelajaran matematika di tingkat SMP/ sederajat. 30\% siswa mengatakan bahwa matematika di tingkat SMP itu menyenangkan, karena gurunya yang mendukung dan penyabar, sehingga 70\% materi SMP dapat dikuasai. Sedangkan 40\% siswa mengatakan bahwa matematika di tingkat SMP tidak terlalu menyenangkan, dan 20\% dari siswa Mosharafa: Jurnal Pendidikan Matematika Volume 8, Nomor 2, Mei 2019 Copyright $\odot 2019$ Mosharafa: Jurnal Pendidikan Matematika 
mengatakan bahwa matematika di tingkat SMP tidak menyenangkan. Yang menjadi latar belakang matematika di tingkat SMP tidak terlalu menyenangkan dan tidak menyenangkan adalah materinya yang selalu rumit dan susah untuk dimengerti.

Seluruh siswa sepakat bahwa SPLDV telah diajarkan di tingkat SMP, tepatnya di kelas VIII SMP. Namun, hanya 50\% siswa yang menganggap SPLDV mudah, sisanya 40\% menganggap tidak terlalu mudah, dan 10\% mengatakan SPLDV sukar. Sedangkan alasan dari sukarnya SPLDV adalah guru yang terlalu cepat saat menjalaskan materi, saat guru menyampaikan materi tidak dapat diterima oleh siswa, cara-cara dalam menyelesaikan SPLDV ribet. Sedangkan ada salah satu alasan mengapa siswa menganggap bahwa SPLDV itu mudah, karena siswa tersebut merasa senang dengan materi tersebut.

Sedangkan selama pembelajaran mengenai SPLTV, siswa mengalami peningkatan dalam menyelesaikan soalsoal yang serupa dengan itu. Siswa juga memberikan tanggapannya mengenai tingkat kesulitan dalam menjawab SPLTV. 40\% dari siswa mengatakan bahwa SPLTV tergolong materi yang mudah, karena tanpa disadari secara langsung SPLTV dapat diterapkan dalam kehidupan seharihari, bisa dimengerti dan mudah untuk dipahami. Sedangkan 50\% dari siswa menganggap bahwa SPLTV merukapan materi yang tidak terlalu mudah untuk diselesaikan karena caranya yang panjang, sulit menghafal rumus, dan tergantung soal yang dikerjakannya.

\section{Penutup}

Guru berperan penting dalam pembelajaran matematika untuk membantu penyelidikan siswa dalam menceritakan langkah yang ada dalam pemikirannya. SPLDV sangat berpengaruh dalam membangun pemahaman mengenai SPLTV, karena konsep dasar dalam pembelajaran SPLTV adalah SPLDV. Siswa yang memiliki latar belakang pemahaman SPLDV yang baik cenderung mudah memahami SPLTV.

\section{Daftar PUStaka}

Afriansyah, E. A. (2016). Investigasi Kemampuan Problem Solving dan Problem Posing Matematis Mahasiswa via Pendekatan Realistic. Mosharafa: Jurnal Pendidikan Matematika, 5(3).

Ariani, S., Hartono, Y., \& Hiltrimartin, C. (2017). Kemampan Pemecahan Masalah Matematika Siswa Pada Pembelajaran Matematika Menggunakan Strategi AbduktifDeduktif di SMA Negeri 1 Indralaya Utara. Jurnal Elemen, 3(1).

Hidayat, W., \& Sariningsih, R. (2018). Kemampuan Pemecahan Masalah Matematis dan Adversity Questient Siswa SMP melalui Pembelajaran Open Ended. Jurnal JNPM, 2(1).

Kafiar, E., Kho, R., \& Triwiyono. (2015). Proses Berpikir Siswa SMA Dalam Memecahkan Masalah Matematika Pada Materi SPLTV Ditinjau dari Gaya Kognitif Field Independent dan Field Dependent. Jurnal IImiah Matematika dan Pembelajarannya, 2(1), 48-63. 
Kurniawati, V., \& Rizkianto, I. (2018). Pengembangan Perangkat

Pembelajaran Matematika Berbasis Guided Inquiry dan Learning Trajektory Berorientasi pada Kemampuan Pemecahan Masalah. Mosharafa: Jurnal Pendidikan Matematika, 7(3), 369-380.

Nur, I. A. K., Maya, R., \& Setiawan, W. (2018). Analisis Kemampuan Komunikasi Matematis Siswa SMP pada Materi Statistika. Jurnal Pembelajaran Matematika Inovatif, 1(6).

Rahayu, D. V., \& Afriansyah, E. A. (2015). Meningkatkan

Kemampuan

Pemecahan Masalah Matematik Siswa Melalui Pembelajaran Pelangi Matematika. Mosharafa: Jurnal Pendidikan Matematika, 5(1).

Riduan. (2007). Dasar-dasar Statistika. Bandung: Alfabeta.

Ruseffendi, E. T. (1990). Pengajaran Matematika Modern dan Masa Kini. Bandung: Tarsito.

Sanjaya, W. (2013). Penelitian Pendidikan Jenis, Metode, dan Prosedur. Jakarta: Kencana Prenada Media Group.

Setiawan, S. (2015). Meningkatkan Kemampuan Berpikir Kritis Matematis Siswa SMP dengan Menggunakan Model Penemuan Terbimbing. Jurnal IImiah UPT P2M STKIP Siliwangi, 2(1).

Siswono, T. Y. E. (2018). Pembelajaran Matematika Berbasis Pengajuan dan Pemecahan Masalah. Bandung: Remaja Rosdakarya.

Sumarmo, U., Hidayat, W., Zukarnaen, R., Hamidah, M., \& Sariningsih, R. (2012). Kemampuan dan Disposisi Berpikir Logis, Kritis, dan Kreatif Matematik (Eksperimen terhadap Siswa SMA Menggunakan Pembelajaran Berbasis
Masalah dan Strategi Think-TalkWrite). Jurnal Pengajaran MIPA, 17(1), 17-33.

Zakiyah, S., Imania, S. H., Rahayu, G., \& Hidayat, W. (2018). Analisis Kemampuan Pemecahan Masalah dan Penalaran Matematik Serta Efisiensi Diri Siswa SMA. Jurnal Pembelajaran Matematika Inovatif, 1(4).

\section{Riwayat Hidup PenUlis}

\section{Siti Zakiyah}

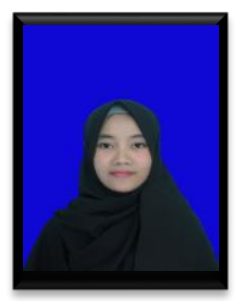

Lahir di Bandung 21 Juli 1996. Mahasiswi jurusan Pendidikan Matematika IKIP Siliwangi angkata 2015. Saat ini sedang menduduki semester 7 .

\section{Dr. Wahyu Hidayat, S.Pd. M.Pd.}

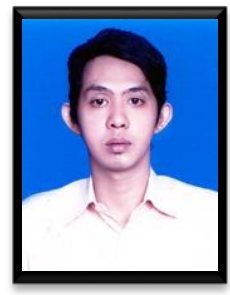

Lahir di Jakarta, 4 Agustus 1984. Dosen sekaligus Kepala Biro Administrasi Akademik dan Kemahasiswaan (BAAK) IKIP Siliwangi. Telah gelar Sarjana Pendidikan di STKIP Siliwangi tahun 2008, gelar Magister Pendidikan pada bidang matematika di Universitas Pendidikan Indonesia tahun 2011, dan gelar Doktor di Universitas Pendidikan Indonesia pada tahun 2018.

Wahyu Setiawan, S.Pd. M.Pd.

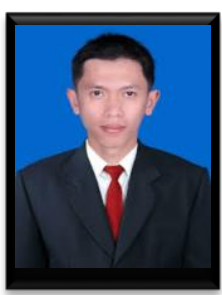

Lahir di Samarinda, 22 Mei 1978. Staff pengajar IKIP Siliwangi. Telah menempuh gelar Sarjana Pendidikan pada bidang matematika di STKIP Siliwangi Bandung tahun 2013, dan gelar Magister Pendidikan di STKIP Siliwangi Bandung pada bidang matematika tahun 2015. 